\title{
The effect of equity structure and influence factors on China's banking cyclical behavior and monetary policy
}

Crentsil Kofi Agyekum

Correspondence: crentsilkofiagyekum@gmail.com Economics and Management Department, Beijing University of Technology, 100 Pingleyuan, Chaoyang District, Beijing, China

\begin{abstract}
Several years ago, there were crises on mortgage that resulted in a serious thread on financial systems in the United States of America and other developed and developing countries. However, some scholars are of the view that the pro-cyclical nature of the bank led to this serious incident. In this study, we focus on China's bank lending behavior whether it falls within the cyclicality of the banking practices. The study realized that credit distributions were still the managerial way of for transferring government monetary policy. It is not however the actual reasons behind the China's bank counter-cyclical lending. State-owned financial firms within higher ownership are of no doubt of likely to be counter cyclical. Some school of thought are with the view that compared to developed countries, state-owned banks play a major decisions in other developing countries such as Brazil, and they believe that the well performances of this nations are adhering to the financial crises that are highly related to the stateowned banks. For example in China, commercial banks are the main embodiment of China's financial institutions. It is believed that most of these banks have very strong support by the central government and that makes clients pay more attention to their well-being thus implementing the states macroeconomic policies and resisting the financial crises. The study based on other existing researches will take the government monetary policy and commercial banks equity structure into a frame work and under search how they influence the cyclical China's commercial bank lending behavior and project other possible effects for regulatory bodies to take it into account when making a decision.
\end{abstract}

Keywords: Monetary policy, Shareholder structure, Lending behavior, Counter-cyclicality

\section{Introduction}

Foreign scholars have done a lot of researches on the relationship between the macroeconomy and commercial bank lending. They have mostly reached an agreement that except some countries with special reasons, most commercial banks' lending behaviors move in the same direction with the macro-economy, the so-called pro-cyclicality phenomenon.

Keynes (1936) finds that commercial bank will adjust its loan standard according to the macro-economy situation to control loan amount, and the change of the loan amount will have a positive feedback to the economy.

Chiuri et al. (2002) choose 15 countries and divide them into two groups according to if they have experienced the financial crisis. One group contains five countries that have not

(c) The Author(s). 2017 Open Access This article is distributed under the terms of the Creative Commons Attribution 4.0 International License (http://creativecommons.org/licenses/by/4.0/), which permits unrestricted use, distribution, and reproduction in any medium, provided you give appropriate credit to the original author(s) and the source, provide a link to the Creative Commons license, and indicate if changes were made. 
experienced the financial crisis like India, and the other group consists of ten countries that have not undergone the crisis such as Brazil. They find that the bank' lending of the latter group have more significant pro-cyclicality.

Foos (2009) picks the data of 950 banks in Germany, Tabak (2011) picks the data of 134 banks in Brazil, and Stolz and Wedow (2011) pick the data of 2631 banks of West Germany. They all well verify the pro-cyclicality of commercial bank lending behavior.

Akinboade and Makina (2009) adopt the descriptive statistical method to study the commercial banks of South Africa from both macro and micro level, and they generally find the pro-cyclicality of lending behavior significant.

When referring to the reasons of pro-cyclicality, different scholars hold different opinions. The main views include the information asymmetry of financial market, the "natural" pro-cyclical characteristic of bank operation, and the theories on the procyclicality of capital regulation.

Bernanke and Gertler (1989), Kiyotaki and Moore (1997) find there exists information asymmetry among financial market. When the economy goes down, it will be more difficult for the bank to evaluate the credit of the corporations borrowing money. For the sake of prudence, bank will cut down the loan, leading to the pro-cyclicality of its lending.

\section{Literature review}

Famer $(1985,1988)$, Smith (1995), Asea and Bloomberg $(1997,1998)$ demonstrate that bank may adjust its loan standard according to the economic condition. When the economy goes up, it will lower the standard, and when the economy goes down, it will raise that standard. This kind of adjustment results in the pro-cyclicality of lending, amplifying the fluctuation of macro-economy.

Kashyap and Stein (2004), White (2006), and Tabak (2011) all illustrate that the procyclicality characteristics of loan loss provisions, prices of collaterals, and capital do lead to the pro-cyclicality of bank lending.

Nowadays, some domestic scholars start to study the relationship between the commercial bank lending and the macro-economy, and they get different results.

(1)Some scholars find that Chinese bank lending is pro-cyclical.

Hua and Xiao (2007) use the multivariate GARCH model, and they suggest that Chinese commercial bank lending behavior is pro-cyclical.

$\mathrm{Lu}$ and Li (2009) employ fixed-effect model, classify Chinese commercial banks into five classes, and calculate loan loss reserves with discounted future cash flow. They find these banks have obvious pro-cyclical features.

Fan and He (2009) suggest that Chinese bank's business expanding speed, asset quality, risk management, operating income, and profit all have apparent pro-cyclical characteristic.

Lin (2011) reports that Chinese bank lending is pro-cyclical through Granger causality test.

Sun (2012) also gets the same conclusion, and she believes this pro-cyclicality has brought adverse effect to the economy.

(2)Some scholars find that Chinese bank lending is counter-cyclical. 
Chen and Gong (2011) uses the cycle filtering method to analyze the quarterly data of banks' loan amount and the GDP from 1991 to 2010. They find the loan is pro-cyclical sometimes, and it is counter-cyclical during other time especially after subprime mortgage crisis.

Huang and Xiong (2013) pick the annual unbalanced panel data to 45 banks from 2000 to 2010 and use the one step system GMM method, demonstrating that Chinese bank lending behavior is counter-cyclical.

Pan (2011) applies the qualitative analysis method and reports that under the effect of a series of financial rescue policies after the subprime mortgage crisis, Chinese banks show typical counter-cyclicality. Pan (2013) picks the annual unbalanced panel data of 23 Chinese banks from 2003 to 2011 and gets the same results as Huang and Xiong (2013).

Shen (2014) uses the two step system GMM method to study the annual data of 37 Chinese banks from 2003 to 2012 and draws the same conclusion as Pan (2013). Besides that, she classifies the loan into mortgage loan, corporate loan, and individual consumption loan and studies the cyclicality respectively. The result shows that corporate loan and individual consumption loan are counter-cyclical, but the mortgage loan has the opposite feature.

Since the 1930s, different economic genres have put forward different kinds of monetary policy transmission theories. The transmission can be classified into money channel and credit channel according to the substitutability of financial assets except currency.

Many scholars prove that the credit channel for monetary policy transmission does exist. They employ data from different countries and different methodology, and demonstrate that under the prerequisite of information asymmetry and incomplete development of financial market, commercial banks play a critical role in transmitting the monetary policy, and their lending behavior will have significant effect on the consequence.

Bernanke (1986) builds VAR model and reports that the shock of American banks' loan has great influence on the total demand.

Zhou and Jiang (2002) study the transmission mechanism of Chinese monetary policy between 1993 and 2001. They find that both credit channel and money channel do exist, but the former one plays the main role.

Jiang, Liu and Zhao (2005) study the narrow money, broad money and loan amount to find which one is better to be the medium target. In their paper, they build two VAR models with M1 and M2 and use impulse response analysis method. They report that loan amount has the most significant effect on the final target, then the M2, while M1 is the least significant one. However, in terms of stability and persistence, M1 is the best.

Sheng and Wu (2008) pick the monthly data from 1998 to 2006 to analyze the transmission channel and medium target of monetary policy. They find M2 can well explain the changes of macro-economy like industrial added value, but interest rate index like interbank rate lacks explanatory power. Besides, they design VAR model and conduct Granger causality test, finding that loan is the Granger reason of M2, and both loan and M2 are the Granger reason of industrial added value. In a nutshell, credit channel plays key medium role in monetary policy transmission while not interest channel.

Zhao and Liu (2013) choose the monthly data from 2004 to 2012 and build several VAR models. They employ Granger causality test and co-integration test to find the transmission mechanism of monetary policy. They report that Chinese loan amount and M2 are the interrelationships of cause and effect, and loan amount can boost investment, GDP, and CPI apparently. Credit channel is of great efficiency. However, 
there are many researches regarding the banks' equity structure and its lending behavior, but few of them study the cyclicality of bank lending from the ownership structure perspective. Research findings vary based on different methods and samples. In general, state-owned bank lending is less pro-cyclical than that of private bank.

(1)Cross-countries study show that equity structure has more significant effect on bank lending cycle in developing countries than that of developed ones. Even though among developing countries, significances are still quite different.

Micco and Panizza (2006) use the pooled countries' panel data and report that state owned bank lending is less pro-cyclical compared with private bank. They believe it is not because of the laziness of state-owned banks' managers, while it is because the state-owned bank has the duty to smooth loan and stabilize the economy.

Pan and Zhang (2013) analyze the annual unbalanced panel data of 23 Chinese banks from 2003 to 2011 and report that the loan growth rate shows significant countercyclical characteristic. The increase in the shareholding ratio of the largest shareholder and the proportion of state-owned shares will strengthen the counter-cyclicality of gross loans. The increase in the proportion of foreign shares will weaken this countercyclicality.

Shen (2014) draws the same conclusion as Pan and Zhang (2013) through studying the annual panel data of 37 Chinese banks from 2003 to 2012. Besides that, she classifies the loan into mortgage loan, corporate loan, and individual consumption loan to study their cyclicality, respectively. She reports that mortgage loan is pro-cyclical while corporate and individual consumption loans are counter-cyclical.

\section{Methodology}

According to Zhang (2011), since China began massive industrialization in 1953, China has undergone 11 business cycles as shown in Table 1.

Since we are studying the lending behavior of bank over cycles, our samples at least contain one economic cycle. Most of Chinese banks had finished shareholding reform by 2005. So we choose all the 143 banks' data from 2005 to 2014, reject those banks whose time span is less than 4 years, and in the end, we get the 10-year annual unbalanced data of 33 banks. Our sample includes state-owned specialized banks, 11 joint-equity commercial banks, and 18 city commercial banks. The sample includes 2 business cycles, and the total assets of these 33 banks account for $70.05 \%$ of that of the whole Chinese banking, so the sample is representative and can reflect the overall characteristics of Chinese bank lending.

Among the 33 banks, 16 of them have been listed in a share market (including the 4 state-owned specialized banks, 9 joint-equity banks, and 3 city commercial banks) The 16 listed banks' financial data are collected from Wind database, while that of the rest 17 banks are collected from BVD-Bank scope database. In terms of the equity structure data of the 33 banks, we choose them through their annual reports one by one. From Wind database and the National Bureau of Statistics of the PRC, we get the macro-economy data.

Referring to Cull (2012), Pan and Zhang (2013), we design the individual fixed effect model as our basic econometric model for empirical analyses, and it is as below. 
Table 1 Business cycles of China

\begin{tabular}{lll}
\hline Cycle order & Period & Duration (years) \\
\hline 1 & $1953-1957$ & 5 \\
2 & $1958-1962$ & 5 \\
3 & $1963-1968$ & 6 \\
4 & $1969-1972$ & 4 \\
5 & $1973-1976$ & 4 \\
6 & $1977-1981$ & 5 \\
7 & $1982-1986$ & 5 \\
8 & $1987-1990$ & 4 \\
9 & $1991-2001$ & 11 \\
10 & $2002-2007$ & 6 \\
11 & $2008-$ Now & 8 \\
\hline
\end{tabular}

$$
\operatorname{loan}_{\mathrm{i}, \mathrm{t}}=\beta_{0}+\beta_{1} \text { gdp }_{\mathrm{t}}+\sum_{\mathrm{i}=2}^{6} \beta_{\mathrm{i}} \operatorname{control}_{\mathrm{i}, \mathrm{t}}+\mathrm{u}_{\mathrm{i}}+\varepsilon_{\mathrm{i}, \mathrm{t}}
$$

In the model above, $\operatorname{loan}_{i, t}$ represents the real loan growth of bank $i$ in year $t, \operatorname{gdp}_{t}$ means the real GDP growth, control ${ }_{i, t}$ is five control variables, $u_{i}$ shows the fixed-effect term of bank $i$, and $\varepsilon_{i, t}$ is the error term (Table 2). We will interpret the definition and calculation of each variable specifically in section 3.3. We have some basic interpretation and description for the model 3.1.

(1) In our sample, $N=33, T=10$, and it is a short panel dataset.

Table 2 Definition of variable

\begin{tabular}{|c|c|c|c|}
\hline \multicolumn{2}{|l|}{ Variable } & \multirow{2}{*}{$\begin{array}{l}\text { Meaning } \\
\text { Growth rate of gross loan }\end{array}$} & \multirow{2}{*}{$\frac{\text { Calculation }}{\frac{\operatorname{loan}_{i, t}}{\operatorname{loan}_{i, t-i}}-1}$} \\
\hline $\begin{array}{l}\text { Dependent } \\
\text { variable }\end{array}$ & $\operatorname{loan}_{i, t}$ & & \\
\hline Explanatory & $g d p_{t}$ & Growth rate of real GDP & $\frac{\mathrm{GDP}_{t}}{\mathrm{GDP}_{t-1}}-1$ \\
\hline \multirow[t]{7}{*}{ variable } & $\operatorname{iav}_{t}$ & $\begin{array}{l}\text { Growth rate of industrial } \\
\text { added value }\end{array}$ & Growth rate of industrial added value of year $t$ \\
\hline & state $_{i, t}$ & Characteristic of bank & $\begin{array}{l}\text { Equals to } 1 \text { if the largest shareholder is government } \\
\text { and government holds more than } 20 \% \text { of total } \\
\text { equity, or more than } 50 \% \text { of total equity is } \\
\text { controlled by government, and } 0 \text { otherwise. }\end{array}$ \\
\hline & fshare $_{i, t}$ & Share of the biggest shareholder & Share of the biggest shareholder \\
\hline & share $5_{i, t}$ & Shares of top five shareholders & Shares of top five shareholders \\
\hline & dep_r $r_{t}$ & $\begin{array}{l}\text { Annual change of one-year } \\
\text { benchmark deposit rate }\end{array}$ & The rate at the end of year $t$ minus that of year $t-1$ \\
\hline & loan_r ${ }_{t}$ & $\begin{array}{l}\text { Annual change of one-year } \\
\text { benchmark loan rate }\end{array}$ & The rate at the end of year $t$ minus that of year $t-1$ \\
\hline & res_r $r_{t}$ & $\begin{array}{l}\text { Annual change of large financial } \\
\text { institution deposit reservation } \\
\text { rate }\end{array}$ & The rate at the end of year $t$ minus that of year $t-1$ \\
\hline \multirow{5}{*}{$\begin{array}{l}\text { Control } \\
\text { variable }\end{array}$} & size $_{i, t}$ & Log of banks' total asset & $\operatorname{Ln}(\text { total asset })_{i, t}$ \\
\hline & $\operatorname{car}_{i, t}$ & Capital adequacy ratio & Capital adequacy ratio of bank $i$ of year $t$ \\
\hline & $\mathrm{dtt}_{i, t}$ & Liquidity & $\frac{\text { deposit }_{i, t}}{\text { loan }_{i, t}}$ \\
\hline & $\mathrm{roa}_{i, t}$ & Return on asset & $\frac{\text { net income }}{(\text { tot, }}$ \\
\hline & crisis $_{t}$ & Financial crisis & If $t=2008,2009$ and 2010,equals 1,otherwise 0 \\
\hline
\end{tabular}


(2)The current value of GDP is subject to reverse causality, meaning that the current GDP growth and current loan growth could cause each other, which may leads to endogeneity problem.

(3) When analyzing the short panel dataset, the basic problems facing us is that we should choose the fixed-effect model or random effect model. To verify our model, we use Hausman test and prove fixed effect model is better.

(4) Some scholars like Pan (2013) adopts dynamic panel data model, treats the 1-year lag of loan growth as the explanatory variable, and uses the system GMM method to estimate the coefficients. At the beginning of research, we use the model as Pan (2013) to do regression on the same data, but the estimated sign of $\operatorname{loan}_{i, t-1}$ is negative, which is quite the opposite as previous researches, what is worse, the coefficient is not significant. From the side view, it confirms the validity of individual fixed effect model.

\section{Variables}

As this paper wants to find the relationship between Chinese bank lending and the fluctuation of macro-economy, and how monetary policy and equity structure impose effect on their relationship, the explained variable in our model is the loan growth rate, and GDP growth rate, monetary policy and equity structure are the main explanatory variables. To control the effect of banks' own features, we add five control variables into the model.

\section{Dependent variable}

Referring to Foos (2009) and Duprey (2012), we use the growth rate of gross loan to represent the changes of commercial banks' loan scale.

\section{Explanatory variable}

When studying the macro-economy issues, current scholars has two kinds of indexes to measure the fluctuation of macro-economy, one is the gross GDP growth rate, the other is the average GDP growth rate. Since in this paper we want to find the relationship between banks' loan scale and the whole economy situation, we employ the gross GDP growth rate to avoid the effect of population. In robustness test part, we will use the growth rate of industrial added value to replace the gross GDP rate.

The target of monetary policy includes operation target and medium target. Compared with the medium objective, the operation target is closer to the policy setting, and is of high operability, so we choose the operation target as the proxy variable of monetary policy. Specifically, the operation target includes the annual change of the large financial institutions' deposit reservation rate, the annual change of the 1-year benchmark deposit rate, and the annual change of the 1-year benchmark loan rate. In China, the deposit reservation rate and benchmark deposit and loan rates are the most common operating tools with obvious effects.

Equity structure contains two aspects; one is the concentration of shares, and the other is the characteristic of the controlling shareholder. So we will study the effect of equity structure from the two aspects. According to the previous paper, there are several indexed to represent the concentration of shares, including the share of the biggest shareholder, the 
shares of the top five owners, the HHI of the top five owners, and kind of staff. Referring to Pan (2013), we choose the share of the biggest shareholder, and in the robustness test part, we use the share of the top five shareholders instead. In terms of the characteristic of owner, we want to classify if the bank is state owned or private. Based on Laporta (1999), in general, shareholder with more than $20 \%$ shareholding ratio can take the control position. Thus, we define a bank to be state-owned bank if the largest shareholder is government and government holds more than $20 \%$ of total equity, or more than $50 \%$ of shares are held by the government and state-owned corporation. The proxy variable of characteristic of shareholders is a dummy variable, which equals 1 when the bank is state-owned, otherwise it is 0 .

\section{Control variable}

We add the financial crisis dummy variable to control the effect of subprime mortgage crisis on banks' loan. In the year 2008 to 2010, it equals 1 and it equals 0 otherwise. To defend against the crisis, during this period, Chinese government took series of investment plans such as the "four trillion plan" to boost the economy.

Other control variables are chosen according to Jia (2009), Cull and Peria (2013), and Berger (2002, 2005), and are as below.

First is the banks' size. Big banks, especially the "Big 4" in China, they have a huge loan base, so the loan growth rate is relatively low. On the contrary, small bank's absolute amount of new loan is less than big bank, but it has a relatively high loan growth rate. We use the log of banks' total asset to control the effect of banks' size.

The second is capital adequacy ratio. High capital adequacy reflects the managers of banks are risk-averse, and they do not make full use of capital, leading to the loan growth rate slow down.

The fourth is liquidity. We use the ratio of total deposit over total loan to represent liquidity. High liquidity means that bank has more deposit source for a certain amount of loan, and the loan scale may expand further.

The last is the profitability. We use the return on asset to represent banks' profitability. High return on asset will stimulate the bank to expand their loan scale further.

\section{D. model design}

\section{D.1 hypotheses}

Based on background review and related data, Chinese banks show different lending over cycles compared with other developed countries. So we put forward the first hypothesis.

H1: Chinese bank lending behavior is counter-cyclical.

Commercial banks are still the main component of Chinese financial system, loan from commercial banks is still the main source of external financing for most Chinese enterprises, and the credit channel is the most important way for Chinese government to transmit its monetary policies. Pan (2013) and Shen (2014) do not take the monetary policy factor into consideration when they study Chinese bank lending over cycles, and they do not explain the counter-cyclicality phenomenon of their findings. Under this circumstance, we put forward the second hypothesis.

H2: credit channel is effective for transmitting government's monetary policy, and this is the critical reason for the counter-cyclicality of Chinese bank lending.

High leverage ratio is one of the main features of banks, and the shareholders are less risk averse and have more incentive to pursue profit (White, 2011). In contrast, the managers of 
banks are more risk averse and prudent because they care more about their occupational risk and the effects of performance on their reputation (Fahlenbrach and Stulz, 2011). If there is no controlling shareholder and the equities are relatively decentralized, the daily business of bank will manifest the managers' will more. To be specific, when the economy goes up, they will strictly control the quantity and quality of new loan and avoid expanding business blindly, when the economy drop down, they suffer from less loan losses. That kind of lending reflects less pro-cyclicality. So we put forward the third hypothesis.

H3: lending of banks with low shareholding concentration is more counter-cyclical than that of banks with high shareholding concentration.

Chinese state-owned banks, especially the big four specialized banks, are more than just commercial banks. Besides maximizing profit, state-owned banks still carry social and political functions. They are responsible to smooth economic fluctuation to maintain the stability of macro-economy. So we put forward the fourth hypothesis.

H4: state-owned bank lending is more counter-cyclical than non-state-owned banks.

\section{Results and discussion}

Referring to Wong (2012) and Pan (2013), we first design the basic model to study the relationship between bank lending and macro-economy fluctuation. The model is as below.

$$
\operatorname{loan}_{\mathrm{i}, \mathrm{t}}=\beta_{0}+\beta_{1} \text { gdp }_{\mathrm{t}}+\sum_{\mathrm{i}=2}^{6} \beta_{\mathrm{i}} \operatorname{control}_{\mathrm{i}, \mathrm{t}}+\mathrm{u}_{\mathrm{i}}+\varepsilon_{\mathrm{i}, \mathrm{t}}
$$

Where the explained variable $\operatorname{loan}_{i, \mathrm{t}}$ represents the loan growth of bank $i$ in year $t$. $\operatorname{gdp}_{\mathrm{t}}$ means the GDP growth rate of China at year $t$. According to H1, Chinese bank lending is counter-cyclical. When the economy accelerates, the growth rate of loan will decrease, when the economy slows down, the growth rate of loan will increase. The estimated sign for $\beta_{1}$ is negative.

$\operatorname{control}_{i, t}$ represents other control variables concerning banks own features, including crisis $_{t}, \operatorname{car}_{i, t}, \mathrm{dtl}_{\mathrm{i}, \mathrm{t}}, \operatorname{size}_{i, t}$, roa $_{i, t}$.

$\operatorname{crisis}_{t}$ is the financial crisis dummy variable. In the year 2008 to 2010, it equals 1 and it equals 0 otherwise. To defend against the crisis, during this period, Chinese government took series of investment plans such as the "four trillion plan" to boost the economy, and the loan scale increases significantly. The estimated sign of $\beta_{2}$ is positive.

$\operatorname{car}_{i, t}$ is capital adequacy ratio. High capital adequacy reflects the managers of banks are risk-averse, and they do not make full use of capital, leading to the loan growth rate slow down. The estimated sign of $\beta_{3}$ is negative.

$\mathrm{dtl}_{i, t}$ is liquidity. High liquidity means that bank has more deposit source for a certain amount of loan, and the loan scale may expand further. The estimated sign of $\beta_{4}$ is negative.

size $_{i, t}$ represents the total asset of bank. Small banks' loan growth rate is higher than big banks. The estimated sign of $\beta_{5}$ is negative.

roa $_{i, t}$ is the profitability. We use the return on asset to represent banks' profitability. High return on asset will stimulate the bank to expand their loan scale further. The estimated sign of $\beta_{6}$ is positive. 


$$
\operatorname{loan}_{i, t}=\beta_{0}+\beta_{1} \text { gdp }_{t}+\sum_{i=2}^{6} \beta_{i} \operatorname{control}_{i, t}+\beta_{7} m_{t}+u_{i}+\varepsilon_{i, t}
$$

Based on the basic model in section D.2, we plug in the proxy variable of monetary policy to prove that the credit channel is effective and try to explain the countercyclicality of Chinese bank lending. Other variables are the same as those in basic model.

$\mathrm{mp}_{t}$ means the change of Chinese monetary policy. In China, deposit reservation rate and deposit and loan benchmark rate is the operation tools which the central bank usually use. In model 3.3, we have three monetary policy variables, and they are the annual change of the large financial institutions' deposit reservation rate, the annual change of the 1-year benchmark deposit rate and the annual change of the 1-year benchmark loan rate. During the regression, we plug the three variables into the model one by one and get three results. In real operation, the central bank often uses joint tools, meaning using the reservation rate and bench-mark interest rate together. So we will use the combination of two tools out of the three to do analyses.

When the economy is in recession, the central bank will decrease the reservation rate and benchmark interest rate to increase the currency supply. When the economy is prosperous, the central bank will raise these rates to avoid overheated economy and control inflation. The estimated sign of $\beta_{7}$ should be negative. Besides, according to $\mathrm{H} 2$, we assume that after adding the monetary policy factor, the coefficient of gdp $\mathrm{p}_{\mathrm{t}}$ will become not significant or even become positive.

$$
\operatorname{loan}_{i, t}=\beta_{0}+\beta_{1} \operatorname{gdp}_{t}+\sum_{\mathrm{i}=2}^{6} \beta_{\mathrm{i}} \operatorname{control}_{i, t}+\beta_{7} \mathrm{mp}_{t}+\beta_{8} \text { structure }_{i, t}+\beta_{9} \operatorname{structure}_{i, t}{ }_{*} \operatorname{gdp}_{t}+\mathrm{u}_{i}+\varepsilon_{i, t}
$$

Based on the model in section 3.4.3, we focus on the effect of banks' equity structure on its lending over cycles. Other variables are the same as those in basic model.

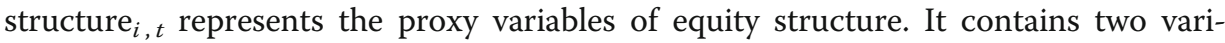
ables, the first is fshare $i_{i, t}$ which means the biggest owner's share and reflects the concentration of equity, the second is state ${ }_{i, t}$ which is equal to 1 when the bank belongs to the government and equals 0 when it is private.

Since we want to demonstrate the effect of equity structure on bank lending over cycles, while no effect on commercial banks' loan growth, we will add the cross term of equity structure and macro-economy into the model, and that is fshare ${ }_{i, t}^{*} \operatorname{gdp}_{t}$ and state ${ }_{i, t}^{*} \operatorname{gdp}_{t}$. If the sign of $\beta_{9}$ is positive, that means the equity structure variable will make bank lending less counter-cyclical. If the sign is negative, that means the equity structure variable will increase the counter-cyclicality of bank lending behavior. According to H3, the estimated signs of fshare ${ }_{i, t}^{*} \mathrm{gdp}_{t}$ and state ${ }_{i, t}^{*} \operatorname{gdp}_{t}$ should be positive and negative separately.

To get the intuitive relationship between commercial bank lending and the macroeconomy fluctuation, we choose the GDP growth data and the total loan of banking from 2000 to 2014, and draw the line graph as indicated in Fig. 1.

From Fig. 1, we can see that from 2000 to 2007, Chinese economy kept accelerating, and even grew with a speed more than $10 \%$ after 2004. During the same period, the total loans show great fluctuations and dropped significantly from 2000 to 2001 and from 2003 to 2005. Suffering from the financial crisis, Chinese economy decelerated obviously from 2007 to 2009, while the total loans were rocketing, reaching the peak at 2009. After that, 


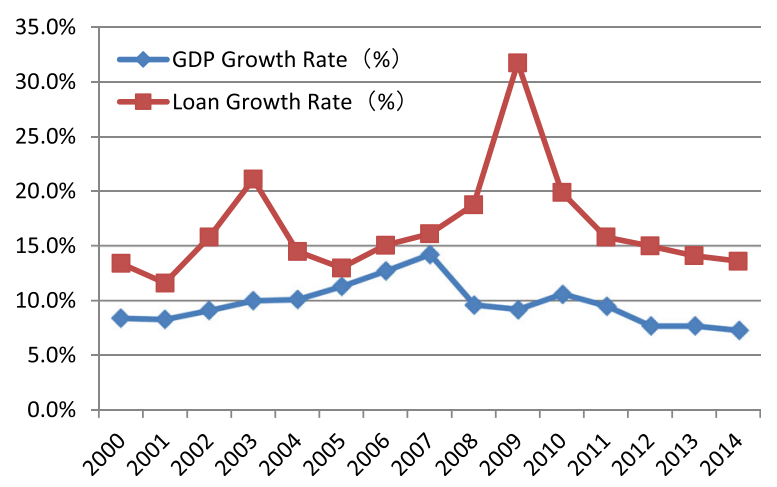

Fig. 1 Growth Rates of GDP and Total Loans from 2000 to 2014

benefiting from the "four trillion plan", GDP growth rate increased in the following 2 years, but the economy downturn was still a serious problem facing the government. In general, the total loan did not move in the same direction with GDP, but showed apparent countercyclical features especially in the following years after the crisis. This phenomenon is quite different from that in some developed countries, so in the following section, we will use the quantitative methods to more precisely study the bank lending over cycles and other factors.

Most of Chinese banks had finished shareholding reform by 2005. So we choose all the 143 banks' data from 2005 to 2014, reject those banks whose time span is less than 4 years, and in the end, we get the 10-year annual unbalanced data of 33 banks. A glance at Table 3 shows the average loan growth rate for state-owned banks and non-state-owned banks are 0.15 and 0.18 , respectively, while the average size of state-owned bank is larger than that of non-state-owned banks by 1.94. So size of bank seems to be negatively correlated with loan growth. The study also find that the average share percentage of the biggest owner of stateowned banks is 0.35 , which is almost twice the number of non-state-owned banks. The share of biggest shareholder also seems to have negative relationship with loan growth, and this corresponds to former theoretical analyses. Regarding other variables, no significant differences we can see between the two groups.

\section{Variables correlation test}

Before econometric regression, this section will in advance analyze the correlation of variables involved, and the test result is shown in Table 4. We can find that except the correlation between the 1-year benchmark deposit rate and loan rate is as high as 0.9591 , other correlations between any two variables are no more than 0.6927 . So when we take the combination of monetary policy tools into the model, we will not put the benchmark deposit rate and benchmark loan rate together in order to avoid the multicollinearity problem.

The correlation between gdp and loan is 0.0155 , showing the pro-cyclical feature, but it is not significant. Except capital adequacy ratio, other control variables are significantly correlated with loan growth rate, and the sign of correlation is the same as we assume in section II. Through analyzing the relationship between loan and monetary policy factor, we conclude that credit channel for policy transmission is effective in China, but the correlation coefficient is positive, which is different from what we know. In the end, we report the 


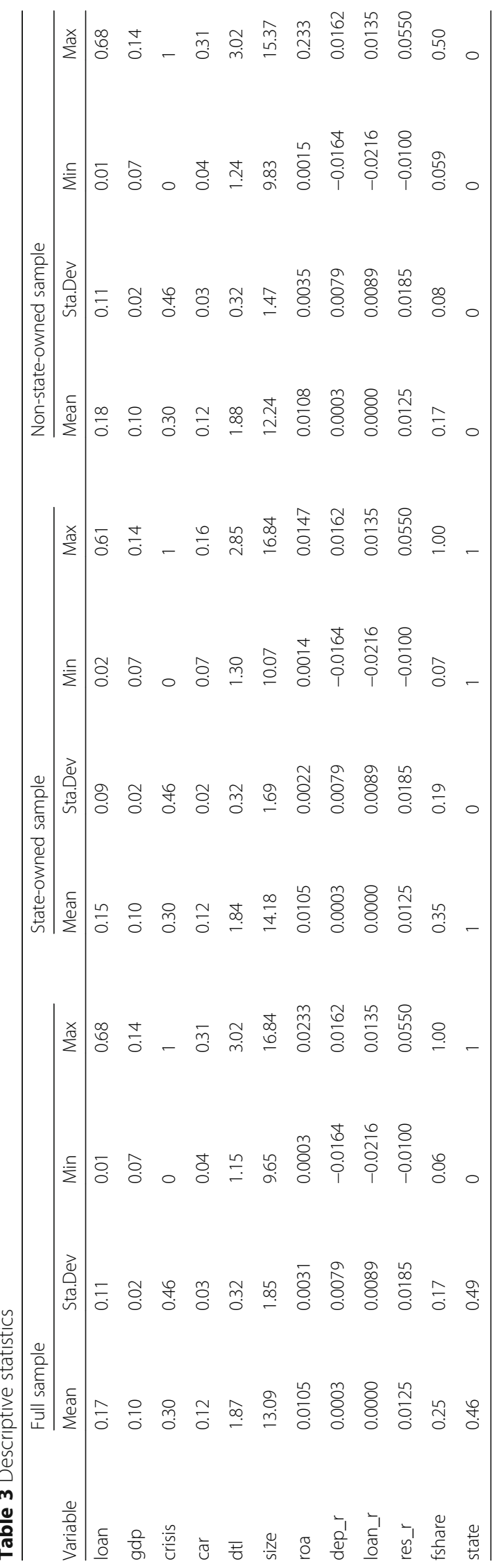




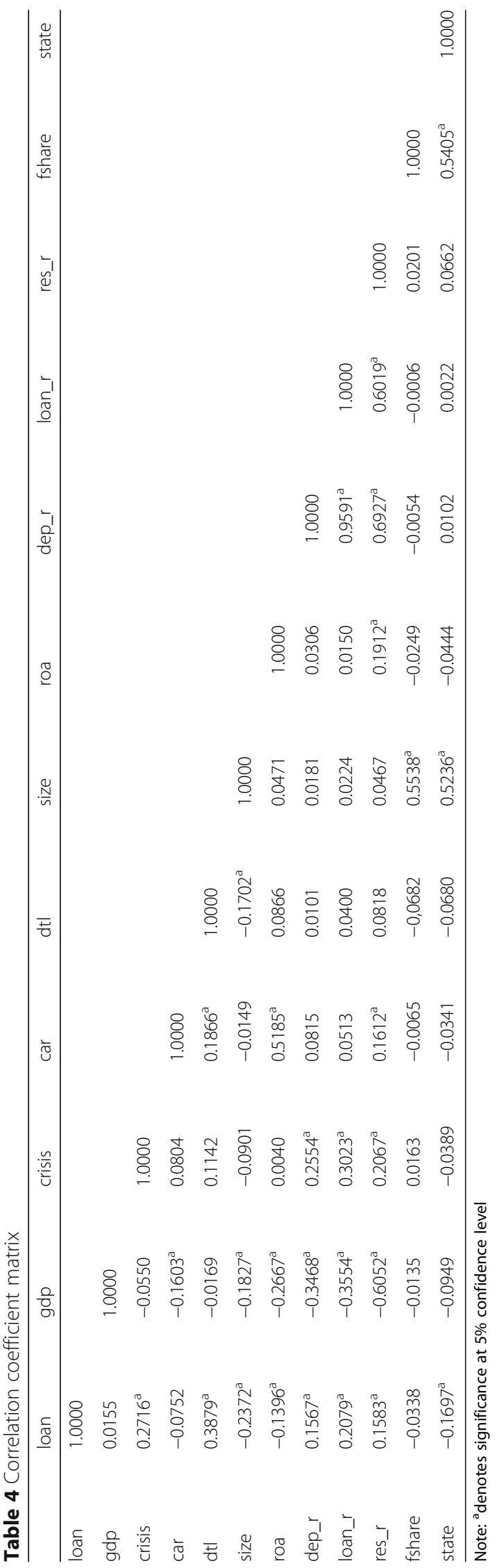


correlations between loan and equity structures are all negative, but only the correlation between state and loan is significant.

According to the three econometric models we design, we first study the basic model 2, and report the relationship between Chinese bank lending and macroeconomy. Then we plug the three monetary policy variables and their combinations into the basic model and get model 3, in order to demonstrate that monetary policy has great effects on bank lending over cycles. In the end, we take the equity structure variables and the cross term of equity structure and GDP into consideration and get model 4 , trying to find the characteristics of bank lending with different equity structure.

In Table 5, the first column shows the regression results of the basic model 2. The second to the fourth column are the results when we plug in the 1-year benchmark deposit rate, 1-year benchmark loan rate and large financial institution deposit reservation rate, respectively. In the fifth column, we take the combination of 1-year bench-mark deposit rate and large financial institution deposit reservation rate. Similarly with column 5 , the sixth column includes the combination of 1-year benchmark loan rate and large financial institution deposit reservation rate.

From the first column, we find the coefficient between gdp and loan growth rate is -2.6929 , and it is significant at $1 \%$ confidence level. Once the gdp increases $1 \%$,

Table 5 Effect of monetary policy on bank lending over business cycles

\begin{tabular}{|c|c|c|c|c|c|c|}
\hline Variables & (i) & (ii) & (iii) & (iv) & (v) & (vi) \\
\hline \multirow[t]{2}{*}{$g d p$} & $-2.6929^{* * * *}$ & $-3.1378^{* * * *}$ & $-3.1451^{* * * *}$ & $-4.0962^{* * *}$ & $-4.0920^{* * *}$ & $-4.0970^{* * *}$ \\
\hline & $(-8.79)$ & $(-9.34)$ & $(-9.23)$ & $(-10.06)$ & $(-9.38)$ & $(-10.08)$ \\
\hline \multirow[t]{2}{*}{ crisis } & $0.0364^{* * *}$ & $0.0411^{* * *}$ & $0.0441^{* * *}$ & $0.0488^{* * *}$ & $0.0488^{* * *}$ & $0.0504^{* * *}$ \\
\hline & $(3.51)$ & (3.94) & $(4.20)$ & $(4.28)$ & $(4.21)$ & $(4.53)$ \\
\hline \multirow[t]{2}{*}{ car } & $-0.6160^{* *}$ & $-0.6732^{* *}$ & $-0.6603^{* *}$ & $-0.6463^{* *}$ & $-0.6470^{* *}$ & $-0.6603^{* *}$ \\
\hline & $(-2.48)$ & $(-2.64)$ & $(-2.61)$ & $(-2.68)$ & $(-2.64)$ & $(-2.67)$ \\
\hline \multirow[t]{2}{*}{$\mathrm{dtl}$} & $0.1430^{* * *}$ & $0.1507^{* * *}$ & $0.1449^{* * *}$ & $0.1629^{* * *}$ & $0.1629^{* * *}$ & $0.1611^{* * * *}$ \\
\hline & $(4.87)$ & $(5.00)$ & $(4.79)$ & (5.32) & $(5.27)$ & (5.08) \\
\hline \multirow[t]{2}{*}{ size } & $-0.1165^{* * *}$ & $-0.1227^{* * *}$ & $-0.1213^{* * *}$ & $-0.1242^{* * *}$ & $-0.1242^{* * *}$ & $-0.1251^{* * *}$ \\
\hline & $(-6.05)$ & $(-6.24)$ & $(-6.26)$ & $(-6.30)$ & $(-6.26)$ & $(-6.35)$ \\
\hline \multirow[t]{2}{*}{ roa } & $8.9119^{* *}$ & $8.6661^{* *}$ & $8.3480^{* *}$ & $9.0760^{* *}$ & $9.0695^{* *}$ & $8.8251^{* *}$ \\
\hline & $(2.28)$ & $(2.22)$ & $(2.12)$ & $(2.37)$ & $(2.34)$ & $(2.25)$ \\
\hline \multirow[t]{2}{*}{ dep_r } & & $-1.4844^{* * *}$ & & & -0.0301 & \\
\hline & & $(-5.86)$ & & & $(-0.05)$ & \\
\hline \multirow[t]{2}{*}{ loan_r } & & & $-1.3192^{* * *}$ & & & -0.5369 \\
\hline & & & $(-4.61)$ & & & $(-1.28)$ \\
\hline \multirow[t]{2}{*}{ res_r } & & & & $-1.5158^{* * *}$ & $-1.5014^{* * *}$ & $-1.3178^{* * *}$ \\
\hline & & & & $(-4.95)$ & $(-2.83)$ & $(-3.22)$ \\
\hline R-squ (within) & 0.4035 & 0.4493 & 0.4493 & 0.4659 & 0.4659 & 0.4678 \\
\hline Observations & 241 & 241 & 241 & 241 & 241 & 241 \\
\hline No of banks & 33 & 33 & 33 & 33 & 33 & 33 \\
\hline Hausman test $p$ value & 0.0000 & 0.0000 & 0.0000 & 0.0000 & 0.0000 & 0.0000 \\
\hline
\end{tabular}

Note: ${ }^{* * *},{ }^{* *}{ }^{*}$ denote the significance at 1,5 , and $10 \%$ confidence level. The value in the bracket below reports the $t$ value in $t$ test. R-squ means the goodness of fit. The Hausman Test $p$ value shows the $p$ in Hausman test, which is employed to prove if the fixed effect model is better than random effect model 
banks' loan growth rate will drop $2.6929 \%$, and this reports the counter-cyclicality of bank lending. The result corresponds to H1, and is the same as what Pan (2013) finds with different model.

From column 2 to column 4, we demonstrate all the coefficients of the three monetary policy variables are significant at $1 \%$ confidence level, and the estimated values are $-1.4844,-1.3192$, and -1.5158 , separately. When plugging in the monetary policy variables, the coefficient of gdp drop from -2.6929 to -4.0962 , and it is still significant at $1 \%$. The goodness of fit increases from 0.4035 to 0.4659 . Through the description above, we conclude that credit channel is still effective for Chinese government to use monetary policy tools to control banks' loan scale, but it is not the reason why Chinese bank lending is counter-cyclical. This conclusion differs from $\mathrm{H} 2$.

From the fifth and sixth column, we find when we take the combination of monetary policy variables into the model, dep_r and loan_r become not significant, but res_r keeps significant at $1 \%$ level. We think this is because deposit reservation rate is the more essential and direct factor on loan than benchmark interest rate. When we put the combination into the model, the explanatory power of dep_r $r$ and loan_ $r$ is absorbed by res_r. So in the following regression concerning the equity structure, we only use res_r $\mathrm{r}$ as the monetary policy variable.

The $p$ value of Hausman test is 0.0000 , so we reject the null hypopaper and verify that the fixed effect model is more suitable than random effect model.

\section{D.2 equity structure, macro-economy, and bank lending}

In Table 6, the first column shows the results without the equity structure factor, which is the same as the fourth column in Table 5. In the second column, we add the fshare and the cross term of fshare and gdp. In the third column, we add the state and the cross term of state and gdp. In the last column, we put the fshare and state and their cross terms with gdp together into the model.

In section D.2, we mainly focus on the coefficient of the cross term. In the column 2, the coefficient of fshare"gdp is -1.6071 , and significant at $5 \%$ confidence level. The results report that banks with high share concentration show more counter-cyclical lending behavior that banks with low concentration. The result is quite the opposite as the $\mathrm{H} 3$.

In the column 3, the coefficient of state"gdp is -1.2404 and significant at $1 \%$ confidence level. The results correspond to the H3. State-owned banks, especially the big four, are playing an important role in smoothing the loan scale and promoting the economy a stable increase. So the lending of state-owned bank is more counter-cyclical than that of non-state-owned bank.

In column 4, when we put fshare and state together into the model, changes happen. The coefficients of state and state"gdp are still significantly negative, which are the same as column 3, but the coefficients of fshare and fshare"gdp become not significant. Regarding the reasons, we believe fshare and state are relatively highly correlated, the correlation coefficient is 0.5405 . When we put them together, the explanatory power of fshare is absorbed by state. This explanation can also account for the results in column 2 which is different from H3. In China, stateowned bank usually has high share concentration, while the share of the biggest owner in non-state-owned bank is relatively small. 
Table 6 Effects of equity structures on bank lending over business cycles

\begin{tabular}{|c|c|c|c|c|}
\hline Variables & (I) & (ii) & (iii) & (iv) \\
\hline \multirow[t]{2}{*}{ gdp } & $-4.0962^{2^{* * *}}$ & $-3.6539^{a * * *}$ & $-4.1117^{a^{* * *}}$ & $-3.9382^{a^{* * *}}$ \\
\hline & $(-10.06)$ & $(-8.01)$ & $(-9.33)$ & $(-8.73)$ \\
\hline \multirow[t]{2}{*}{ crisis } & $0.0488^{a^{* * *}}$ & $0.0481^{a^{* * *}}$ & $0.0428^{\mathrm{a}^{* * *}}$ & $0.0434^{\mathrm{a}^{* * *}}$ \\
\hline & $(4.28)$ & $(4.26)$ & $(3.61)$ & (3.72) \\
\hline \multirow[t]{2}{*}{ car } & $-0.6463^{\mathrm{b}^{* *}}$ & $-0.6866^{\mathrm{a}^{* *}}$ & $-0.7341^{\mathrm{b}^{* *}}$ & $-0.7322^{\mathrm{a}^{* * *}}$ \\
\hline & $(-2.68)$ & $(-2.79)$ & $(-2.43)$ & $(-2.77)$ \\
\hline \multirow[t]{2}{*}{$\mathrm{dtl}$} & $0.1629^{\mathrm{a}^{* * *}}$ & $0.1673^{\mathrm{a}^{* * * *}}$ & $0.1786^{\mathrm{a}^{* * *}}$ & $0.1733^{\mathrm{a}^{* * *}}$ \\
\hline & $(5.32)$ & $(5.22)$ & $(4.99)$ & $(4.90)$ \\
\hline \multirow[t]{2}{*}{ size } & $-0.1242^{\mathrm{a}^{* * * *}}$ & $-0.1229^{a * * *}$ & $-0.1388^{\mathrm{a}^{* * * *}}$ & $-0.1366^{\mathrm{a}^{* * *}}$ \\
\hline & $(-6.30)$ & $(-6.38)$ & $(-6.13)$ & $(-7.37)$ \\
\hline \multirow[t]{2}{*}{ roa } & $9.0760^{b^{* *}}$ & $8.8865^{b^{* *}}$ & $7.1814^{c^{* *}}$ & $6.5943^{c^{* *}}$ \\
\hline & $(2.37)$ & $(2.26)$ & (1.84) & $(1.74)$ \\
\hline \multirow[t]{2}{*}{ res_r } & $-1.5158^{8^{* * * *}}$ & $-1.5330^{a * * *}$ & $-1.5710^{\mathrm{a}^{* * *}}$ & $-1.5168^{\mathrm{a}^{* * *}}$ \\
\hline & $(-4.95)$ & $(-4.75)$ & $(-4.73)$ & $(-4.69)$ \\
\hline \multirow[t]{2}{*}{ fshare } & & $0.3347^{a^{* * * *}}$ & & 0.2289 \\
\hline & & $(2.90)$ & & $(1.66)$ \\
\hline \multirow[t]{2}{*}{ state } & & & $0.1218^{\mathrm{a}^{* * * *}}$ & $0.1292^{\mathrm{a}^{* * *}}$ \\
\hline & & & (3.04) & $(3.26)$ \\
\hline \multirow[t]{2}{*}{ fshare ${ }^{c} g d p$} & & $-1.6071^{b^{* *}}$ & & -0.2045 \\
\hline & & $(-2.06)$ & & $(-0.22)$ \\
\hline \multirow[t]{2}{*}{ state $^{c} \mathrm{gdp}$} & & & $-1.2404^{\mathrm{a}^{\mathrm{a**}}}$ & $-1.4489^{a^{* * *}}$ \\
\hline & & & $(-2.84)$ & $(-3.21)$ \\
\hline R-squ (within) & 0.4659 & 0.4758 & 0.4887 & 0.5058 \\
\hline Observations & 241 & 238 & 237 & 237 \\
\hline No of Banks & 33 & 33 & 33 & 33 \\
\hline Hausman Test $p$-value & 0.0000 & 0.0000 & 0.0000 & 0.0000 \\
\hline
\end{tabular}

Note: ${ }^{* *} a, b, c$ denote the significance at 1,5 , and $10 \%$ confidence level. The value in the bracket below reports the $t$ value in $t$ test. R-squ means the goodness of fit. The Hausman test $p$ value shows the $p$ in Hausman test, which is employed to prove if the fixed effect model is better than random effect model

Regarding the control variables, the results are almost the same as previous analyses. The coefficient of crisis keeps around 0.04 and significant at $1 \%$ dtl and size are all significant at $1 \%$ level, with coefficient of 0.15 and -0.12 . After plugging in car and roa, their coefficients decrease from -0.6 to -0.7 and decrease from 8.9 to 6.6, respectively, and are becoming less significant.

\section{Robustness test}

In order to ensure the validity, in this section the study did some robustness tests. We replaced the GDP growth rate with industrial added value growth rate and replace the share of the biggest owner with the shares of the top five shareholders to test if the results in section still hold when we change the form of our explanatory variables.

Similarly, we replace the gdp with iav. We first study the basic model 2 and report the relationship between Chinese bank lending and macro-economy. Then 
we plug the three monetary policy variables and their combinations into the basic model and get model 3 , in order to demonstrate that monetary policy has great effects on bank lending over cycles. In the end, we take the equity structure variables and the cross term of equity structure with the industrial added value into consideration and get model 4, trying to find the characteristics of bank lending with different equity structure. The results are reported in Tables 7 and 8 , which are almost the same as those in section D, verifying the robustness of our model.

\section{Replacing the share of biggest shareholder with that of top five shareholders}

In this section, we use the share of top five shareholders instead of the share of the biggest shareholders. The results are reported in Table 9 in the Appendix, and robustness is checked.

\section{Conclusions}

In this paper, the author chose the annual unbalanced panel data of 33 Chinese commercial banks from 2005 to 2014, design individual fixed effect model, and combined the literature researches with empirical analyses. The study reported the characteristics of Chinese bank lending behaviors over business cycles and reported the effects of

Table 7 Robustness test for effect of monetary policy on bank lending over business cycles

\begin{tabular}{|c|c|c|c|c|c|c|}
\hline Variables & (i) & (ii) & (iii) & (iv) & (v) & (vi) \\
\hline \multirow[t]{2}{*}{ iav } & $-1.2488^{a}$ & $-1.6186^{a}$ & $-1.7002^{a}$ & $-1.9325^{a}$ & $-1.9043^{\mathrm{a}}$ & $-2.0999^{b}$ \\
\hline & $(-5.63)$ & $(-6.09)$ & $(-6.30)$ & $(-6.14)$ & $(-6.01)$ & $(-6.68)$ \\
\hline \multirow[t]{2}{*}{ crisis } & $0.0192^{c}$ & $0.0189^{c}$ & $0.0221^{\mathrm{b}}$ & $0.0187^{c}$ & $0.0187^{c}$ & $0.0212^{\mathrm{b}}$ \\
\hline & $(1.83)$ & $(1.79)$ & $(2.12)$ & $(1.77)$ & $(1.77)$ & $(2.04)$ \\
\hline \multirow[t]{2}{*}{ car } & $-0.7806^{\mathrm{a}}$ & $-0.8448^{\mathrm{a}}$ & $-0.8338^{b}$ & $-0.8306^{\mathrm{a}}$ & $-0.8521^{\mathrm{a}}$ & $-0.8589^{a}$ \\
\hline & $(-2.81)$ & $(-2.94)$ & $(-2.92)$ & $(-2.98)$ & $(-2.98)$ & $(-2.99)$ \\
\hline \multirow[t]{2}{*}{$\mathrm{dtl}$} & $0.1551^{\mathrm{a}}$ & $0.1651^{\mathrm{a}}$ & $0.1594^{\mathrm{a}}$ & $0.1738^{\mathrm{a}}$ & $0.1729^{\mathrm{a}}$ & $0.1720^{\mathrm{a}}$ \\
\hline & $(5.24)$ & (5.35) & $(5.22)$ & $(5.36)$ & $(5.23)$ & (5.16) \\
\hline \multirow[t]{2}{*}{ size } & $-0.0958^{a}$ & $-0.1053^{\mathrm{a}}$ & $-0.1061^{a}$ & $-0.1026^{a}$ & $-0.1060^{\mathrm{a}}$ & $-0.1088^{a}$ \\
\hline & $(-4.28)$ & $(-4.49)$ & $(-4.59)$ & $(-4.41)$ & $(-4.48)$ & $(-4.62)$ \\
\hline \multirow[t]{2}{*}{ roa } & $9.5372^{b}$ & $9.5020^{b}$ & $9.1372^{b}$ & $10.0551^{b}$ & $9.8335^{b}$ & $9.5914^{b}$ \\
\hline & $(2.24)$ & $(2.25)$ & $(2.16)$ & $(2.34)$ & $(2.28)$ & $(2.22)$ \\
\hline \multirow[t]{2}{*}{ dep_r } & & $-1.5747^{\mathrm{a}}$ & & & -0.6822 & \\
\hline & & $(-5.11)$ & & & $(-1.42)$ & \\
\hline \multirow[t]{2}{*}{ loan_r } & & & $-1.5888^{a}$ & & & -0.7075 \\
\hline & & & $(-5.08)$ & & & $(-1.38)$ \\
\hline \multirow[t]{2}{*}{ res_r } & & & & $-1.1088^{a}$ & $-1.2598^{\mathrm{a}}$ & $-1.2645^{a}$ \\
\hline & & & & $(-3.44)$ & $(-3.24)$ & $(-3.22)$ \\
\hline R-squ (within) & 0.3638 & 0.3983 & 0.3980 & 0.4015 & 0.4018 & 0.4081 \\
\hline Observations & 241 & 241 & 241 & 241 & 241 & 241 \\
\hline No. of banks & 33 & 33 & 33 & 33 & 33 & 33 \\
\hline Hausman test $p$ value & 0.0000 & 0.0000 & 0.0000 & 0.0000 & 0.0000 & 0.0000 \\
\hline
\end{tabular}

Note: ${ }^{\mathrm{a}},{ }^{\mathrm{b}},{ }^{\mathrm{c}}$ denote the significance at 1,5, and 10\% confidence level. The value in the bracket below reports the $t$ value in $t$ test. R-squ means the goodness of fit. The Hausman test $p$ value shows the $p$ in Hausman test, which is employed to prove if the fixed effect model is better than random effect model 
Table 8 Robustness test for effect of equity structure on bank lending over business cycles

\begin{tabular}{|c|c|c|c|c|}
\hline Variables & (i) & (ii) & (iii) & (iv) \\
\hline \multirow[t]{2}{*}{ iav } & $-1.9325^{b}$ & $-1.4950^{a}$ & $-1.8127^{a}$ & $-1.6315^{a}$ \\
\hline & $(-6.14)$ & $(-4.56)$ & $(-5.30)$ & $(-4.80)$ \\
\hline \multirow[t]{2}{*}{ crisis } & $0.0187^{c}$ & $0.0199^{c}$ & $0.0191^{c}$ & $0.0209^{c}$ \\
\hline & $(1.77)$ & $(1.84)$ & $(1.71)$ & $(1.97)$ \\
\hline \multirow[t]{2}{*}{ car } & $-0.8306^{\mathrm{a}}$ & $-0.8542^{\mathrm{a}}$ & $-0.8989^{b}$ & $-0.8919^{\mathrm{a}}$ \\
\hline & $(-2.98)$ & $(-3.08)$ & $(-2.65)$ & $(-2.95)$ \\
\hline \multirow[t]{2}{*}{$\mathrm{dtl}$} & $0.1738^{\mathrm{a}}$ & $0.1779^{\mathrm{a}}$ & $0.1912^{\mathrm{a}}$ & $0.1858^{\mathrm{a}}$ \\
\hline & $(5.36)$ & $(5.25)$ & $(4.99)$ & $(4.97)$ \\
\hline \multirow[t]{2}{*}{ size } & $-0.1026^{\mathrm{a}}$ & $-0.0991^{\mathrm{a}}$ & $-0.1130^{\mathrm{a}}$ & $-0.1100^{\mathrm{a}}$ \\
\hline & $(-4.41)$ & $(-4.61)$ & $(-4.34)$ & $(-5.23)$ \\
\hline \multirow[t]{2}{*}{ roa } & $10.0551^{b}$ & $9.6492^{b}$ & 6.5080 & 6.0394 \\
\hline & $(2.34)$ & $(2.24)$ & $(1.60)$ & (1.54) \\
\hline \multirow[t]{2}{*}{ res_r } & $-1.1088^{\mathrm{a}}$ & $-1.1442^{\mathrm{a}}$ & $-1.1505^{\mathrm{a}}$ & $-1.1160^{\mathrm{a}}$ \\
\hline & $(-3.44)$ & $(-3.29)$ & $(-3.20)$ & $(-3.13)$ \\
\hline \multirow[t]{2}{*}{ fshare } & & $0.4260^{\mathrm{a}}$ & & $0.2928^{b}$ \\
\hline & & $(4.16)$ & & $(2.32)$ \\
\hline \multirow[t]{2}{*}{ state } & & & $0.1780^{\mathrm{a}}$ & $0.1704^{\mathrm{a}}$ \\
\hline & & & $(5.55)$ & $(5.58)$ \\
\hline \multirow[t]{2}{*}{ fshare ${ }^{c} i a v$} & & $-1.6603^{\mathrm{a}}$ & & -0.4995 \\
\hline & & $(-2.95)$ & & $(-0.82)$ \\
\hline \multirow[t]{2}{*}{ state $c_{i a v}$} & & & $-1.3049^{\mathrm{a}}$ & $-1.3518^{\mathrm{a}}$ \\
\hline & & & $(-5.82)$ & $(-6.28)$ \\
\hline R-squ (within) & 0.4015 & 0.4132 & 0.4515 & 0.4720 \\
\hline Observations & 241 & 238 & 237 & 237 \\
\hline NO. of Banks & 33 & 33 & 33 & 33 \\
\hline Hausman Test $p$-value & 0.0000 & 0.0000 & 0.0000 & 0.0000 \\
\hline
\end{tabular}

Note: ${ }^{\text {a }}{ }^{\mathrm{b}}, \mathrm{c}$ denote the significance at 1,5 , and $10 \%$ confidence level. The value in the bracket below reports the $t$ value in $t$ test. R-squ means the goodness of fit. The Hausman test $p$ value shows the $p$ in Hausman test, which is employed to prove if the fixed effect model is better than random effect model

monetary policy and equity structure on the cyclicality of lending. The study made three main conclusions as below.

(1)Compared with other countries, Chinese bank lending behaviors are countercyclical. That is to say the fluctuation in bank lending is generally in the opposite direction with the fluctuation of macro-economy. When the economy is prosperous, banks will tighten lending to avoid over-heated economy, and when the economy is in recession, banks will expand loans to boost economy.

(2)Credit channel as the main way of transmitting monetary policies is effect and efficient, but this is not the reason why Chinese bank lending show countercyclicality characteristic. When we plug the monetary policy factor into the model, the counter-cyclicality of lending behavior does not change.

(3)Lending of banks within higher ownership concentration is more countercyclical than banks with lower ownership concentration. Lending of stateowned banks is more counter-cyclical than non-state-owned banks. 


\section{Appendix A}

Table 9 Robustness test for effect of equity structure on bank lending over business cycles

\begin{tabular}{|c|c|c|c|c|}
\hline Variables & $(1)$ & $(2)$ & (3) & (4) \\
\hline \multirow[t]{2}{*}{ gdp } & $-4.0962^{b}$ & $-3.8419^{\mathrm{a}}$ & $-4.1117^{a}$ & $-4.4322^{\mathrm{a}}$ \\
\hline & $(-10.06)$ & $(-6.11)$ & $(-9.33)$ & $(-7.07)$ \\
\hline \multirow[t]{2}{*}{ crisis } & $0.0488^{\mathrm{a}}$ & $0.0460^{\mathrm{a}}$ & $0.0428^{\mathrm{a}}$ & $0.0434^{\mathrm{a}}$ \\
\hline & $(4.28)$ & (3.94) & $(3.61)$ & $(3.72)$ \\
\hline \multirow[t]{2}{*}{ car } & $-0.6463^{b}$ & $-0.7202^{\mathrm{a}}$ & $-0.7341^{b}$ & $-0.7322^{\mathrm{a}}$ \\
\hline & $(-2.68)$ & $(-2.78)$ & $(-2.43)$ & $(-2.77)$ \\
\hline \multirow[t]{2}{*}{$\mathrm{dtl}$} & $0.1629^{\mathrm{a}}$ & $0.1786^{\mathrm{a}}$ & $0.1786^{\mathrm{a}}$ & $0.1733^{\mathrm{a}}$ \\
\hline & $(5.32)$ & $(4.86)$ & $(4.99)$ & $(4.90)$ \\
\hline \multirow[t]{2}{*}{ size } & $-0.1242^{a}$ & $-0.1284^{a}$ & $-0.1388^{a}$ & $-0.1366^{a}$ \\
\hline & $(-6.30)$ & $(-6.75)$ & $(-6.13)$ & $(-7.37)$ \\
\hline \multirow[t]{2}{*}{ roa } & $9.0760^{b}$ & $8.4784^{b}$ & $7.1814^{c}$ & $6.5943^{c}$ \\
\hline & $(2.37)$ & $(2.08)$ & $(1.84)$ & $(1.74)$ \\
\hline \multirow[t]{2}{*}{ res_r } & $-1.5158^{\mathrm{a}}$ & $-1.6241^{\mathrm{a}}$ & $-1.5710^{\mathrm{a}}$ & $-1.5168^{\mathrm{a}}$ \\
\hline & $(-4.95)$ & $(-4.89)$ & $(-4.73)$ & $(-4.69)$ \\
\hline \multirow[t]{2}{*}{ share5 } & & 0.2266 & & 0.1187 \\
\hline & & $(1.29)$ & & $(0.63)$ \\
\hline \multirow[t]{2}{*}{ state } & & & $0.1218^{\mathrm{a}}$ & $0.1321^{\mathrm{a}}$ \\
\hline & & & $(3.04)$ & (3.16) \\
\hline \multirow[t]{2}{*}{ share $5^{c} \mathrm{gdp}$} & & -0.6865 & & 0.6806 \\
\hline & & $(-0.71)$ & & $(0.68)$ \\
\hline \multirow[t]{2}{*}{ state $^{c} g d p$} & & & $-1.2404^{a}$ & $-1.5096^{\mathrm{a}}$ \\
\hline & & & $(-2.84)$ & $(-3.17)$ \\
\hline R-squ (within) & 0.4659 & 0.4801 & 0.4887 & 0.5014 \\
\hline Observations & 241 & 238 & 237 & 237 \\
\hline No of Banks & 33 & 33 & 33 & 33 \\
\hline Hausman Test $p$-value & 0.0000 & 0.0000 & 0.0000 & 0.0000 \\
\hline
\end{tabular}

Note: ${ }^{\mathrm{a}}, \mathrm{b}, \mathrm{c}$ denote the significance at 1,5, and $10 \%$ confidence level. The value in the bracket below reports the $t$ value in $t$ test. R-squ means the goodness of fit. The Hausman Test $p$ value shows the $p$ in Hausman test, which is employed to prove if the fixed effect model is better than random effect model

\section{Acknowledgements}

I am grateful to Beijing University of Technology for supporting this research work. I also acknowledge all staffs of international college (BJUT).

I wish to acknowledge Professor. Huang Haifeng in the School of Economics and Management at Beijing University Technology for his supervision. My sincere appreciation goes to Amma Agyeiwaa. Finally, I would like to thank all my classmates and friends at Beijing University of technology for their support.

\section{Funding}

This study has no funding.

Availability of data and materials

The data that support the findings of this study can be obtained from the author based on request.

\section{Authors' information}

Mr. Crentsil Kofi Agyekum is a PhD candidate and belongs to the Department of Economics and Management in Beijing University of Technology.

Ethics approval and consent to participate

Ethical approval and consent to participate is not applicable for our study. 
Competing interests

The author declares that he/she has no competing interests.

Received: 6 May 2017 Accepted: 11 July 2017

Published online: 22 August 2017

\section{References}

Akinboade OA, Makina D (2009) Bank Lending and Business Cycles: South African Evidence. Afr Dev Rev 21(3):476-498 Asea PK, Blomberg B (1998) Lending cycles[J]. J Econ 83(1-2):89-128

Bernanke B, Gertler M (1989) Agency Costs, Net Worth, and Business Fluctuations[J]. Am Econ Rev 79(79):14-31

Chen K, Gong L (2011) Lending Cycle: Chinese Economy 1991 2010 [J]. Int Finance Res 12:20-28

Chiuri MC, Ferri G, Majnoni G (2002) The macroeconomic impact of bank capital requirements in emerging economies: past evidence to assess the future[J]. J Bank Financ 26(5):881-904

Fahlenbrach R, Stulz RM (2011) Bank CEO incentives and the credit crisis. J Financ Econ 99(1):11-26

Fan Z, He C (2009) Dialectical Views towards the Rapid Growth of Bank Loan [J]. Finance Forum 6:5-12

Huang X, Xiong Q (2013) Bank Capital Buffer, Lending Behavior and Macro-economy: Evidence from China [J]. Int Finance Res 1:52-65

Jiang Y, Liu Y, Zhao Z (2005) Empirical Analyses On the Efficiency of Money Channel and Credit Channel for Transmitting Monetary Policy [J]. Finance Res 5:70-79

Kashyap A, Stein JC (2004) Cyclical implications of the Basel II capital standards. Econ Perspect 28(1):18-31

Kiyotaki N, Moore J (1997) Credit cycles. J Polit Econ 105(2):211-248

Micco A, Panizza U (2006) Bank ownership and lending behavior [J]. Econ Lett 93(2):248-254

Pan M, Zhang Y (2013) Does Equity Structure Have Effect on Bank Lending over Business Cycles: Evidence from Chinese Banking [J]. Finance Res 4:29-42

Stolz and Wedow (2005) German banks, finding evidence of ..... Berrospide, J. and Edge, R. M. (2010).

Submit your manuscript to a SpringerOpen ${ }^{\circ}$ journal and benefit from:

- Convenient online submission

- Rigorous peer review

- Open access: articles freely available online

- High visibility within the field

- Retaining the copyright to your article

Submit your next manuscript at $\gg$ springeropen.com 